\title{
EVALUATION OF NEUTROPHIL-LYMPHOCYTE AND PLATELET-LYMPHOCYTE RATIOS AS PREDICTORS OF 30-DAY MORTALITY IN PATIENTS HOSPITALIZED FOR AN EPISODE OF ACUTE DECOMPENSATED HEART FAILURE
}

\author{
PROCENA ODNOSA NETUTROFILA-LIMFOCITA I TROMBOCITA-LIMFOCITA \\ KAO PREDIKTORA 30-DNEVNE SMRTNOSTI PACIJENTA HOSPITALIZOVANIH \\ ZBOG AKUTNOG SRČANOG OŠTEĆENJA
}

\author{
Gianni Turcato1, Fabian Sanchis-Gomar ${ }^{2}$, Gianfranco Cervellin ${ }^{3}$, Elisabetta Zorzi ${ }^{4}$, \\ Valentina Sivero ${ }^{1}$, Gian Luca Salvagno ${ }^{5}$, Andrea Tenci ${ }^{1}$, Giuseppe Lippi ${ }^{5}$ \\ ${ }^{1}$ Department of Emergency Medicine, G. Fracastoro Hospital of San Bonifacio, \\ Azienda Ospedaliera Scaligera, San Bonifacio, Verona, Italy \\ ${ }^{2}$ Leon H. Charney Division of Cardiology, New York University School of Medicine, New York, USA and \\ Department of Physiology, Faculty of Medicine, University of Valencia and INCLIVA \\ Biomedical Research Institute, Valencia, Spain \\ ${ }^{3}$ Emergency Department, University Hospital of Parma, Parma, Italy \\ ${ }^{4}$ Department of Cardiology and Intensive Care Cardiology, G. Fracastoro Hospital of San Bonifacio, \\ Azienda Ospedaliera Scaligera, San Bonifacio, Verona, Italy \\ ${ }^{5}$ Section of Clinical Biochemistry, University of Verona, Verona, Italy
}

\begin{abstract}
Summary
Background: To investigate the association between both neutrophil to lymphocyte ratio (NLR) and platelet to lymphocyte ratio (PLR) and 30-day mortality in patients hospitalized for an episode of acute decompensated heart failure (ADHF).

Methods: 439 patients admitted to emergency department (ED) for an episode of ADHF. Clinical history, demographic, clinical and laboratory data recorded at ED admission and then correlated with 30-day mortality.

Results: $45 / 439$ (10.3\%) patients died within 30 days from ED admission. The median values of NLR (4.1 vs 11.7 ) and PLR (159.1 vs 285.9) were significantly lower in survivors than in patients who died. The area under the ROC curve of NLR was significantly higher than that of the neutrophil count $(0.76$ vs 0.59 ; $p<0.001)$, whilst the AUC of PLR was significantly better than that of the platelet count $(0.71$ vs $0.51 ; p<0.001)$. In univariate analysis, both
\end{abstract}

\section{Kratak sadržaj}

Uvod: Svrha rada je bila da se ispitaju odnosi povezanosti između neutrofila prema limfocitima (NLR) i trombocita prema limfocitima (PLR) i 30-dnevna smrtnost kod pacijenata koji su hospitalizovani zbog akutnog dekompenzovanog srčanog oštećenja (ADHF).

Metode: U odeljenje hitne medicine (ED) primljeno je 439 pacijenata sa ADHF. Istorija bolesti, demografski i laboratorijski podaci su praćeni prilikom prijema u ED i upoređivani su sa 30-dnevnom smrtnošću.

Rezultati: U toku 30 dana od prijema u ED umrlo je 45/439 $(10,33 \%)$ pacijenata. Srednje vrednosti NLR $(4,11 \mathrm{vs}, 11,7)$ i PLR $(159,1$ vs 285,9$)$ bile su značajno niže kod preživelih u odnosu na preminule pacijente. Površina ispod ROC krive $\mathrm{u}$ NLR bila je značajno viša nego kod iste $u$ broju neutrofila $(0,76$ vs 0,59 ; $p<0,001)$, dok je AUC u slučaju PLR bio značajno bolji nego u odnosu na broj trombocita $(0,71$ vs $0,51 ; p<0,001)$. Univarijantne analize u slučaju oba NLR i

Address for correspondence:

Gianni Turcato

Department of Emergency Medicine,

G. Fracastoro Hospital of San Bonifacio, Azienda Ospedaliera Scaligera, San Bonifacio, Verona, Italy +390456138490,

gianni.turcato@yahoo.it 
NLR and PLR were significantly associated with 30-day. In the fully-adjusted multivariate model, NLR (odds ratio, 3.63) and PLR (odds ratio, 3.22) remained independently associated with 30-day mortality after ED admission.

Conclusions: Routine assessment of NLR and PLR at ED admission may be a valuable aid to complement other conventional measures for assessing the medium-short risk of ADHF patients.

Keywords: acute heart failure, mortality, lymphocytes, monocytes, platelets

\section{Introduction}

Although much progress has been made in diagnosis and management of heart failure (HF) over the past few decades, hospitalizations for acute decompensated heart failure (ADHF) still remain highly frequent and are often associated with medium- and long-term mortality (1-4). HF is a complex and multifaceted syndrome, attributable to various pathological mechanisms which all synergistically contribute to generating structural or functional abnormalities, ultimately culminating in an imbalance between cardiac capacity and peripheral oxygen demand (5).

The most appropriate clinical management of $\mathrm{HF}$ entails a deep understanding of the many factors involved in development of ADHF (6). Along with the potential recognition of innovative therapeutic targets (7), the elucidation of underlying mechanisms behind $\mathrm{HF}$ may lead the way to identify a set of putative biomarkers, which may be used for more reliably predicting patient outcomes (8-10). The prognostic value of many alleged biomarkers has been extensively studied over the past decade $(10,11)$. Among these, both the neutrophil to lymphocyte ratio (NLR) and the platelet to lymphocyte ratio (PLR) ratio were proven to be useful prognostic biomarkers in cardiovascular disease $(12,13)$, and have recently been proposed as potentially useful indicators of immune response activation in ADHF (14).

The role of inflammation in $\operatorname{HF}(15,16)$, and more specifically its contribution to episodes of acute decompensation is still largely debated $(17,18)$. Evidence collected during the last 30 years from in vitro and in vivo studies have helped to elucidate the different immune mechanisms that contribute to triggering systolic dysfunction and progressive alteration of heart structure in patients with chronic $\operatorname{HF}(5,19)$. In acute decompensation, the innate immune response promotes both pro-inflammatory cytokines release and oxidative stress injury, which impair vascular homeostasis and withstand fluid retention $(9,17,20)$. Recently, NLR and PLR have been proposed as reliable indicators of immune activation, inflammation and oxidative stress injury, and their measurement has been considered a valuable tool for predicting mortality in patients with cardiovascular disease $(21,22)$.
PLR bile su značajno povezane za 30-danom. U potpuno podešenom multivarijantnom modelu, NLR (Odds odnos, $2,63)$ i PLR (Odds odnos, 3,22) bili su nezavisno povezani sa 30-dnevnom smrtnošću posle prijema u ED.

Zaključak: Rutinsko praćenje NLR i PLR pri ED prijemu može da bude veoma značajna pomoć uz druga konvencionalna merenja i praćenja radi umanjenja rizika kod ADHF pacijenata.

Ključne reči: akutno srčano oštećenje, smrtnost, limfociti, monociti, trombociti

Therefore, in this retrospective study, we sought to investigate the association between NLR, PLR and 30-day mortality in a cohort of patients hospitalized for an episode of ADHF.

\section{Materials and Methods}

\section{Study population}

This retrospective study was based on all patients consecutively evaluated at the Emergency Department (ED) $(56,000$ visits per year) of the Hospital Girolamo Fracastoro (San Bonifacio, Verona, Italy), between June 2014 and December 2016, and subsequently hospitalized for an episode of ADHF. HF was diagnosed according to the criteria of European Society of Cardiology (ESC) (23), thus including symptoms such as dyspnea, paroxysmal nocturnal dyspnea, respiratory distress, and signs such as peripheral edema, jugular turgor, cough, oliguria, hepato-jugular reflux, tachypnea and pulmonary stasis.

The only inclusion criterion was a diagnosis of $\mathrm{HF}$ already available at ED admission, whilst exclusion criteria were: 1) patients with active cancer and life expectancy $<3$ months; 2) patients on dialysis; 3 ) patients with severe anemia needing urgent blood transfusion; 4) patients undergoing invasive mechanical ventilation; 5) patients with medical conditions known to affect total and differential white blood cell (WBC) count (i.e., hematopoietic diseases, chronic inflammatory conditions, chronic glucocorticoid therapy); 6) patients in whom a complete blood cell count $(\mathrm{CBC})$ was not performed within 24 hours from ED admission.

Clinical history, along with demographic and clinical data, were recorded for all patients at ED admission. Additional information that could always be collected upon ED admission included the New York Heart Association (NYHA) class, echocardiography parameters, ongoing pharmacological treatment, and routine laboratory data.

The 30-day mortality from ED admission was the primary endpoint of this study. Mortality data were obtained by consulting the registry office. This retrospective investigation was performed in accordance 
with the Declaration of Helsinki and was cleared by the local institutional review board.

\section{Laboratory measurements}

The complete blood cell count (CBC) was performed in blood tubes containing $\mathrm{K}_{2}$ EDTA (Terumo Europe NV, Leuven, Belgium), which were always collected at the time of admission to ED. The analysis was performed with the fully-automated hematological analyzer Advia 2120 (Siemens Healthcare Diagnostics, Tarrytown NY, USA). The local reference ranges are $150-400 \times 10^{9} / \mathrm{L}$ for the platelet count, $4.3-10.0 \times 10^{9} / \mathrm{L}$ for total WBC, 2.0-7.0 $\times 10^{9} / \mathrm{L}$ for neutrophils and $0.95-4.5 \times 10^{9} / \mathrm{L}$ for lymphocytes. The entire investigation was carried out using the same analyzer and the quality of results was validated throughout the study period by regular internal quality control procedures and participation in an External Quality Assessment scheme.

\section{Statistical analysis}

The values of NLR and PLR values were respectively calculated by dividing the absolute number of neutrophils or platelets for the absolute counts of lymphocytes, obtained in the same blood sample collected upon ED admission. Results of NLR, PLR and of all the remaining continuous variables were reported as median and interquartile range (IQR), whilst categorical or dichotomous variables were reported as percentage and number of events. Normality of values distribution was evaluated with Kolmogorov-Smirnov test, whereas differences between groups were assessed with Mann Whitney Test, Fischer's Exact Test or Chi-square Test, when appropriate.

The predictive performance of NLR and PLR was assessed by analyzing their respective values as continuous, dichotomic or categorical variable. Since the values of both NLR and PLR were found to be non-normally distributed, they were preliminarily transformed and standardized (mean of 0 and standard deviation of 1) to be used as continuous variables. Patients were also categorized in tertiles according to NLR or PLR values. For testing the relationship with 30-day mortality from ED admission, both NLR and PLR values were dichotomized according to their respective optimal cut-offs as calculated using receiver operating characteristics (ROC) curve analysis.

Univariate and multivariate binary logistic regression models were used to test the association between 30-day mortality from ED admission and both NLR and PLR values. NLR and PLR were entered in the regression models as continuous, categorical or dichotomous variables. Unadjusted and adjusted hazard ratios (HR) were then calculated with their respective 95\% confidence interval $(95 \% \mathrm{Cl})$. The multivariate logistic model for assessing the independent association between 30-day mortality and both NLR and PLR was adjusted for the following variables: age, NYHA class upon ED admission, echocardiography parameters, history of ischemic heart disease, atrial fibrillation and diabetes, as well as for hemoglobin, creatinine, WBC and $C$ reactive protein (CRP) values measured on admission.

Kaplan-Meier curves were finally constructed for assessing the cumulative risk of 30-day mortality from ED admission, and the predictive performance of both NLR and PLR was then evaluated with Log-Rank Test. Statistical significance was set at $p<0.05$. The statistical analysis was performed with STATA statistical software (Stata Corp LP, College Station, TX, USA).

\section{Results}

A total of 466 patients were consecutively admitted to our local ED for an episode of ADHF throughout the study period, 27 of whom ought to be excluded for the presence of one or more exclusion criteria. Therefore, the final study population consisted of 439 eligible patients.

Overall, 45/439 (10.3\%) patients died within 30 days from ED admission. The clinical history and the main demographic, clinical and laboratory data recorded at ED presentation are shown in Table I. The median values of NLR and PLR in the entire study population were 4.5 (IQR, 2.8-7.6) and 171.1 (IQR, 115.7-259.6), respectively.

The distribution of NLR and PLR values in patients who survived and in those who died 30 days after ED admission is shown in Figure 1. The median NLR value was nearly 3 -fold lower in survivors (4.1; IQR, 2.6-6.6) than in patients who died (11.7; IQR, 5.8-26.8; $p<0.001)$. The median PLR value was also significantly lower in survivors (159.1; IQR, 110.9-242.4) than in patients who died (285.9; IQR, 189.1-466.2; $\mathrm{p}<0.001)$.

The 30-day death rate after ED admission was lower in patients in the lowest tertile of NLR $(n=4$; $2.8 \%)$ than in those in the medium $(n=8 ; 5.4 \%)$ and highest tertiles $(n=33 ; 22.1 \% ; p<0.001$ for trend). Likewise, the 30-day mortality after ED admission was also found to be consistently enhanced across increasing tertiles of PLR $(2.8 \%$ vs $9.0 \%$ vs $18.8 \%$; $p$ $<0.001$ for trend)

The optimal cut-offs for predicting mortality 30 days after ED admission were identified by means of ROC curve analysis, and were 5.7 for NLR (i.e., low (L)-NLR 5.7 and high (H)-NLR > 5.7) and 272.9 for PLR (i.e., low (L)-PLR 272.9 and high (H)-PLR $>272.9$ ), respectively (Figure 2). When the entire patient population was stratified according to these 
Table I Clinical history, demographic, clinical and laboratory data recorded in 439 patients admitted to the local emergency department for an episode of acute decompensated heart failure.

\begin{tabular}{|c|c|c|c|}
\hline & Survived & Died & $\mathrm{p}$ \\
\hline Patients, n (\%) & 394 (89.7) & 45 (10.3) & \\
\hline $\begin{array}{l}\text { Sex, } \mathrm{n}(\%)^{*} \\
\text { Men } \\
\text { Women } \\
\text { Age, years (median, IQR) }\end{array}$ & $\begin{array}{l}221(56.1) \\
173(43.9) \\
82(75-86)\end{array}$ & $\begin{array}{l}26(57.8) \\
19(42.2) \\
86(81-91)\end{array}$ & $\begin{array}{l}0.875 \\
0.001\end{array}$ \\
\hline $\begin{array}{l}\text { Clinical history, } \mathrm{n}(\%)^{\star} \\
\text { Ischemic heart disease } \\
\text { Valvular heart disease } \\
\text { Atrial fibrillation } \\
\text { Hypertension } \\
\text { COPD } \\
\text { Chronic renal failure } \\
\text { Diabetes } \\
\text { Ischemic cerebral disease } \\
\text { PAOD } \\
\text { PM/ICD }\end{array}$ & $\begin{array}{l}126(32.0) \\
101(25.6) \\
215(54.6) \\
372(94.4) \\
126(32.0) \\
155(39.3) \\
171(43.4) \\
34(8.6) \\
195(49.5) \\
102(25.9)\end{array}$ & $\begin{array}{l}20(44.4) \\
18(40.0) \\
23(51.1) \\
42(93.3) \\
9(20.0) \\
28(62.2) \\
23(51.1) \\
3(6.7) \\
28(62.2) \\
12(26.7)\end{array}$ & $\begin{array}{l}0.068 \\
0.033 \\
0.387 \\
0.583 \\
0.124 \\
0.003 \\
0.203 \\
0.460 \\
0.072 \\
0.517\end{array}$ \\
\hline $\begin{array}{l}\text { Ongoing therapies, } \mathrm{n}(\%)^{*} \\
\text { Beta-Blockers } \\
\text { ACE inhibitors/Sartans } \\
\text { Loop diuretics } \\
\text { potassium-sparing diuretics } \\
\text { Aspirin } \\
\text { Oral anticoagulant therapy }\end{array}$ & $\begin{array}{l}304(77.2) \\
325(82.5) \\
312(79.2) \\
123(31.2) \\
151(38.3) \\
204(51.8)\end{array}$ & $\begin{array}{l}39(86.7) \\
38(84.4) \\
38(84.4) \\
14(31.1) \\
18(40) \\
23(51.1)\end{array}$ & $\begin{array}{l}0.098 \\
0.466 \\
0.269 \\
0.568 \\
0.473 \\
0.528 \\
\end{array}$ \\
\hline $\begin{array}{l}\text { Cardiac function } \\
\text { EF (continuous) \%, IQR }{ }^{\dagger} \\
\text { EF (conserved); }>45 \%), \mathrm{n}(\%)^{*}\end{array}$ & $\begin{array}{l}43(34-50) \\
169(42.9)\end{array}$ & $\begin{array}{l}37(33-47) \\
12(26.7)\end{array}$ & $\begin{array}{l}0.021 \\
0.025\end{array}$ \\
\hline $\begin{array}{l}\text { NYHA class, } \mathrm{n}(\%)^{\circ} \\
\text { I-II } \\
\text { III-IV }\end{array}$ & $\begin{array}{l}306(77.7) \\
88(22.3)\end{array}$ & $\begin{array}{l}25(55.6) \\
20(44.4)\end{array}$ & 0.002 \\
\hline $\begin{array}{l}\text { Laboratory parameters }^{\dagger} \\
\text { Hemoglobin }(\mathrm{g} / \mathrm{L}) \\
\text { Hematocrit }(\%) \\
\text { Mean corpuscular volume }(\mathrm{fL}) \\
\text { Creatinine }(\mu \mathrm{mol} / \mathrm{L}) \\
\text { C reactive protein }(\mathrm{mg} / \mathrm{L}) \\
\text { Prothrombin time (ratio) }\end{array}$ & $\begin{array}{l}120.3(105.9-134.9) \\
38(33-42) \\
91.8(87.4-96.1) \\
114.9(97.2-159.1) \\
14.1(5.9-35.1) \\
1.34(1.11-2.5)\end{array}$ & $\begin{array}{l}104.3(97.1-126.1) \\
33(31-40) \\
91.1(85.8-99.4) \\
167.9(141.4-203.3) \\
21.8(12.6-89.5) \\
1.42(1.15-2.82)\end{array}$ & $\begin{array}{l}0.046 \\
0.138 \\
0.796 \\
<0.001 \\
0.006 \\
0.604\end{array}$ \\
\hline $\begin{array}{l}\text { White blood cell count } \\
\text { Total White blood cells }\left(\times 10^{9} / \mathrm{L}\right) \\
\text { Neutrophils }\left(\times 10^{9} / \mathrm{L}\right) \\
\text { Lymphocytes }\left(\times 10^{9} / \mathrm{L}\right) \\
\text { Monocytes }\left(\times 10^{9} / \mathrm{L}\right) \\
\text { Platelets }\left(\times 10^{9} / \mathrm{L}\right)\end{array}$ & $\begin{array}{l}7.2(6.0-8.9) \\
5.2(3.8-6.6) \\
1.2(0.8-1.6) \\
0.7(0.5-0.8) \\
189.5(154.0-242.0)\end{array}$ & $\begin{array}{l}7.7(5.7-10.9) \\
6.2(4.4-10.3) \\
0.7(0.3-1.1) \\
0.6(0.3-0.8) \\
179.0(135.0-221.0)\end{array}$ & $\begin{array}{l}0.005 \\
<0.001 \\
<0.001 \\
0.365 \\
0.781\end{array}$ \\
\hline $\begin{array}{l}\text { NLR } \\
\text { Continuous }{ }^{\dagger} \\
\text { Tertiles, n (\%) }^{\circ} \\
\text { I } \\
\text { II } \\
\text { III }\end{array}$ & $\begin{array}{l}4.1(2.6-6.6) \\
139(35.3) \\
139(35.3) \\
116(29.4)\end{array}$ & $\begin{array}{l}11.7(5.8-26.8) \\
4(8.9) \\
8(17.8) \\
33(73.3)\end{array}$ & $\begin{array}{l}<0.001 \\
<0.001\end{array}$ \\
\hline $\begin{array}{l}\text { PLR } \\
\text { Continuous }{ }^{\dagger} \\
\text { Tertiles, n (\%) } \\
\text { I } \\
\text { II } \\
\text { III }\end{array}$ & $\begin{array}{l}159.1(110.9-242.4) \\
141(35.8) \\
132(33.5) \\
121(30.7)\end{array}$ & $\begin{array}{l}285.9(189.1-466.2) \\
4(8.9) \\
13(28.9) \\
28(62.2)\end{array}$ & $\begin{array}{l}<0.001 \\
<0.001\end{array}$ \\
\hline
\end{tabular}

ACE, angiotensin-converting enzyme; COPD, Chronic obstructive pulmonary disease; EF, ejection fraction; NLR, neutrophils to lymphocytes ratio; PLR, platelets to lymphocytes ratio; PAOD, peripheral artery occlusive disease; PM/ICD, permanent pacemaker and implantable cardioverter defibrillator. 


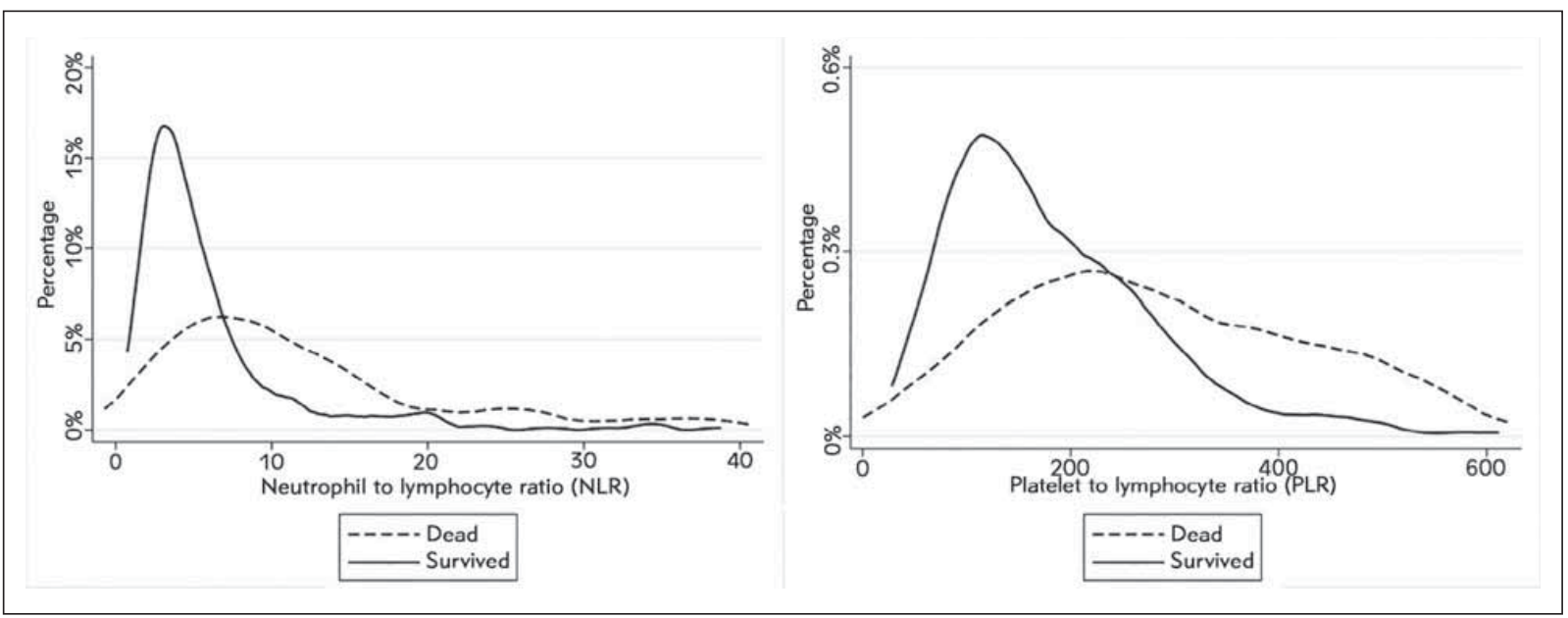

Figure 1 Values distribution of neutrophil/lymphocyte ratio (NLR) and platelet/lymphocyte ratio (PLR) in patients who survive or died 30 days after emergency department admission for an episode of acute decompensated heart failure.

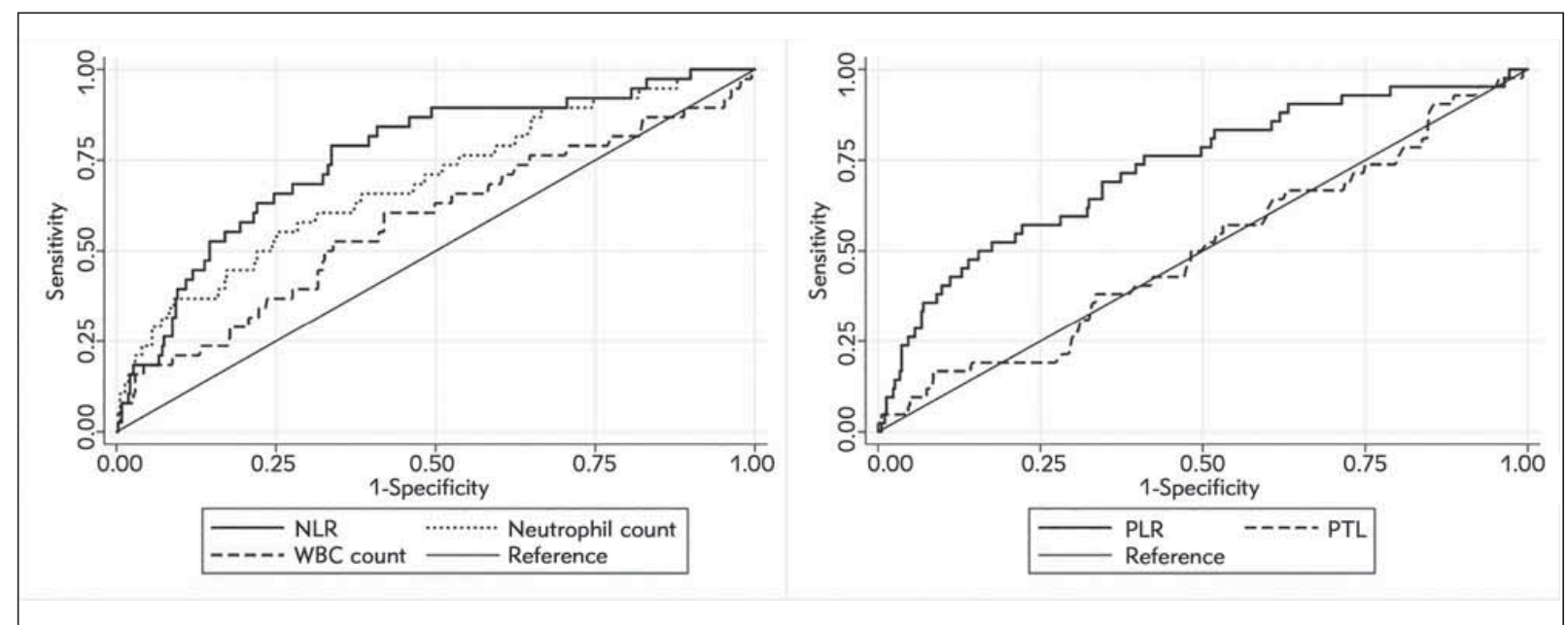

Figure 2 Receiver operating characteristics (ROC) curve analysis for predicting 30-days mortality after emergency department admission for an episode of acute decompensated heart failure.

NLR, neutrophil/lymphocyte ratio; PLR, platelet/lymphocyte ratio; PLT, platelets; WBC, white blood cells.

Table II Univariate and multivariate analysis for predicting 30-days mortality after emergency department admission for an episode of acute decompensated heart failure.

\begin{tabular}{|l|c|c|c|c|}
\hline & Univariate OR (95\% Cl) & $\mathrm{P}$ & $\begin{array}{c}\text { Multivariate adjusted } \\
\text { OR (95\% Cl) }\end{array}$ & $\mathrm{P}$ \\
\hline NLR & & & & \\
Continuous & $2.02(1.46-2.82)$ & $<0.001$ & $1.43(1.05-1.95)$ & 0.022 \\
Tertiles & $3.64(2.18-6.07)$ & $<0.001$ & $2.16(1.15-4.07)$ & 0.017 \\
> optimal cut-off & $6.81(3.34-13.89)$ & $<0.001$ & $3.63(1.49-5.89)$ & 0.005 \\
PLR & $1.92(1.50-2.47)$ & $<0.001$ & $1.63(1.11-2.15)$ & $<0.001$ \\
Continuous & $2.69(1.71-4.24)$ & $<0.001$ & $1.94(1.12-3.35)$ & 0.018 \\
Tertiles & $5.89(3.10-11.20)$ & $<0.001$ & $3.22(1.56-5.68)$ & $<0.001$ \\
> optimal cut-off & &
\end{tabular}

OR, odds ratio; NLR, neutrophil/lymphocyte ratio; PLR, platelet/lymphocyte ratio; $95 \% \mathrm{Cl}, 95 \%$ confidence interval 


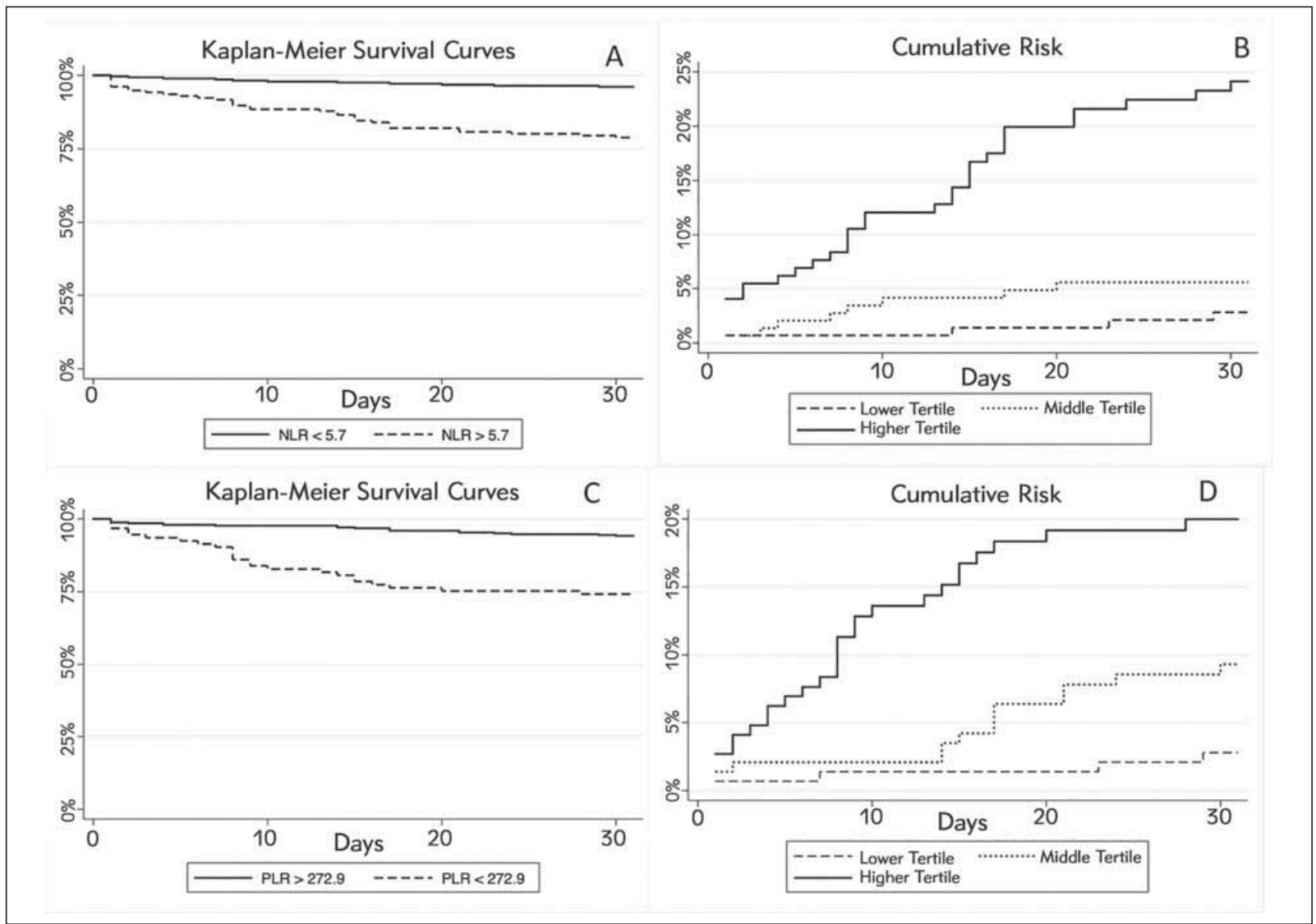

Figure 3 Kaplan-Meyer curves for 30-day mortality in patients admitted to the emergency department for an episode of acute decompensated heart failure. (A) Global survival for patients with NLR over and under the median value; (B) Cumulative death risk according to NLR tertiles; (C) Global survival for patients with PLR over and under the median value; (D) Cumulative death risk according to PLR.

NLR, neutrophil/lymphocyte ratio; PLR, platelet/lymphocyte ratio.

thresholds, increased values of NLR were observed in $75.6 \%(34 / 45)$ of patients who died versus only $31.2 \%(123 / 394)$ of those who survived $(p<0.001)$, whilst increased PLR values were observed in $55.6 \%$ (25/45) of patients who died compared to $17.5 \%$ $(69 / 394)$ of those who survived $(p<0.001)$. The area under the ROC curve (AUC) of NLR was significantly higher than that of the neutrophil count $(0.76$ vs 0.59; $p<0.001)$, whilst the AUC of PLR was significantly better than that of the platelet count (0.71 vs 0.51; $p<0.001)$ (Figure 2).

The results of the univariate and multivariate analyses are shown in Table II. In univariate analysis, both NLR and PLR, either expressed as continuous or as categorical variables, were found to be significantly associated with 30-day mortality after ED admission. In the multivariate model adjusted for age, NYHA class, echocardiography parameters, history of ischemic heart disease, atrial fibrillation, diabetes, and for the values of hemoglobin, creatinine and WBC count at ED presentation, NLR and PLR remained independently associated with 30 days mortality (Table II). These findings were confirmed by Kaplan-Meier analysis (Figures 3). More specifically, the cumulative risk of 30-day mortality was found to be significantly higher for patients in the highest tertile of both NRL (Log Rank, $p<0.001$ ) and PRL (Log Rank, $p<0.001)$, as well as for patients with NLR and PRL values $>5.7$ and $>272.9$, respectively (Log Rank, $p<0.001$ for both).

\section{Discussion}

Several lines of evidence attest that cell-mediated immune response, inflammation and oxidative stress are strongly implicated in the pathogenesis of cardiovascular disease $(9,12,21)$. In effect, classic biomarkers of inflammation such as C-reactive protein, interleukin (IL)-1 and IL-6 has been largely associated with an increased risk of cardiovascular events (24-26). Nonetheless, among the most recent inflammatory biomarkers proposed as potential predictors of outcome in clinical practice $(27,28)$, NLR and PLR are quick and inexpensive tests, and 
have been convincingly associated with the outcome of cardiovascular diseases managed in the ED (21, 22).

In line with these findings, interesting data emerged from our study. We first showed that the values of both NLR and PLR were significantly higher in ADHF patients who died within 30 days of ED admission than in those who survived during the same period. Interestingly, both NLR and PLR remained independently associated with 30-day mortality after adjustment for a large number of demographic, clinical and laboratory data.

Although the clinical significance of NLR is still unclear, an enhanced value of this simple and inexpensive parameter may reflect the existence of a combination between a pro-inflammatory state (i.e., increased neutrophil count) and a concomitant depression of cell-mediated response (i.e., reduced lymphocyte count) (29). A recent study showed that an increased WBC count was associated with higher long-term mortality in patients with chronic HF (30). Leukocyte activation or, more specifically, neutrophil activation in response to various stimuli, may trigger a sustained release of pro-inflammatory cytokines such as interleukin (IL)-1, IL-6, and tumor necrosis factor alpha (TNF-alpha), which may then be responsible for a number of direct, deleterious effects on ventricular function and cardiovascular homeostasis $(31,32)$. Regarding lymphocytes, lymphopenia has been previously associated with increased mortality in ADHF patients with both reduced and preserved ventricular function $(33,34)$. Notably, one single study which investigate the role of NLR for predicting medium- and long-term mortality in patients hospitalized for ADHF has been performed up until now. Specifically, Uthamalingam et al. (14) studied 1212 consecutive patients admitted for ADHF, finally reporting that a NLR value $>7.6$ on admission was associated with enhanced risk of long-term mortality and higher risk of 30-day hospital readmission (14). Moreover, patients in the highest tertile of NLR were found to have a nearly 3 -fold enhanced risk of intrahospital death than those in the lowest tertile (14). Most recently, Benites-Zapata et al. (35) showed that patients with advanced HF and increased values of NLR had an enhanced risk of cardiac transplantation or mortality. Likewise, Durmus et al. (36) also identified an interesting association between increased NLR values and left ventricular systolic EF $(r=-0.409 ; p<0.001)$, thus confirming that sustained release of proinflammatory cytokines and proteolytic enzymes by neutrophils may play an active role in negative cardiac remodeling. The inverse association observed between NLR and mortality in patients admitted to the ED for ADHF can hence be explained with a double-faceted mechanism. On one hand an increased number of circulating neutrophils may promote progression towards a pro-oxidative and prothrombotic state leading to endothelial injury and platelet aggregation (37), whilst a reduced number of circulating lymphocytes may reflect the presence of a physiological stress and an overall immune-metabolic depression, which cannot efficiently counteract oxidative and/or inflammatory injury $(12,38)$.

Regarding PLR, our study is the first to investigate the role of this parameter for predicting short-term outcomes in patients admitted to the ED for ADHF. On different topics, Siniorakis et al. (39) have highlighted a possible role of PLR for the differential diagnosis of dyspnea in the ED. In addition, Durmus et al. (36) demonstrated, in a limited cohort of patients $(n=96)$, that PLR was higher in patients with HF than in healthy controls, though failed to find a significant association with mortality. Hence, further studies are needed for confirming our preliminary data and establishing whether or not this easy and inexpensive parameter may retain a predictive role in ADHF.

Our investigation has some limitations, mainly due to the fact that it is a single-center and retrospective study. Nevertheless, the possibility of studying patients admitted to a middle-size ED with a previous diagnosis of chronic HF before admission (40) has allowed to better reproduce the real-life scenario of a multifaceted condition for which a significant gap still exists between reference centers (which have large experience and availability of advanced treatments) and peripheral facilities (which ordinarily manage this condition in the local district) (32). Another notable drawback is the lack of followup data of both NLR and PLR, which may have allowed the correlation of dynamic changes of these parameters with clinical outcomes.

\section{Conclusions}

ADHF is still a frequently managed condition in many EDs worldwide. A timely and accurate prognostic assessment represents a crucial aspect for tailoring the treatment according to the actual conditions and future risk of the patient. According to our data, routine assessment of both NLR and PLR may therefore be seen as a valuable aid to complement other conventional measures for assessing the medium-short risk of patients admitted to the ED for ADHF.

\section{Conflict of interest statement}

The authors stated that they have no conflicts of interest regarding the publication of this article. 


\section{References}

1. Blecker S, Paul M, Taksler G, et al. Heart failureassociated hospitalizations in the United States. J Am Coll Cardiol 2013; 61: 1259-67.

2. Sperry BW, Ruiz G, Najjar SS. Hospital readmission in heart failure, a novel analysis of a longstanding problem. Heart Fail Rev 2015; 20: 251-8.

3. Collinson P. Laboratory medicine is faced with the evolution of medical practice. J Med Biochem 2017; 36: 211-5.

4. Rørth R, Fosbøl EL, Mogensen UM, et al. Employment status at time of first hospitalization for heart failure is associated with a higher risk of death and rehospitalization for heart failure. Eur J Heart Fail 2018; 20(2): 240-47.

5. Briasoulis A, Androulakis E, Christophides T, et al. The role of inflammation and cell death in the pathogenesis, progression and treatment of heart failure. Heart Fail Rev 2016; 2: 169-76.

6. Gheorghiade M, Zannad F, Sopko G, et al. Acute heart failure syndromes: current state and framework for future research. Circulation 2005; 112: 3958-68.

7. Colombo PC, Doran AC, Onat D, et al. Venous congestion, endothelial and neurohormonal activation in acute decompensated heart failure: cause or effect? Curr Heart Fail Rep 2015; 12: 215-22.

8. Sharma A, Demissei BG, Tromp J, et al. A network analysis to compare biomarker profiles in patients with and without diabetes mellitus in acute heart failure. Eur J Heart Fail 2017; 19: 1310-20.

9. Sabbah HN. Pathophysiology of acute heart failure syndrome: a knowledge gap. Heart Fail Rev 2017; 22: 621-39.

10. de Boer RA, Daniels LB, Maisel AS, et al. State of the Art: Newer biomarkers in heart failure. Eur J Heart Fail 2015; 17: 559-69.

11. Meijers WC, de Boer RA, van Veldhuisen DJ, et al. Biomarkers and low risk in heart failure. Data from COACH and TRIUMPH. Eur J Heart Fail 2015; 17 : 1271-82.

12. Afari ME, Bhat T. Neutrophil to lymphocyte ratio (NLR. and cardiovascular diseases: an update. Expert Rev Cardiovasc Ther 2016; 14: 573-7.

13. Micić D, Stanković S, Lalić AN, ĐUkić V, Polovina S. Prognostic value of preoperative neutrophil-to-lymphocyte ratio for prediction of severe cholecystitis. J Med Biochem 2018; 37: 121-7.

14. Uthamalingam S, Patvardhan EA, Subramanian S, et al. Utility of the neutrophil to lymphocyte ratio in predicting long-term outcomes in acute decompensated heart failure. Am J Cardiol 2011; 107:433-8.

15. Cocco G, Jerie P, Amiet $P$, et al. Inflammation in Heart Failure: known knowns and unknown unknowns. Expert Opin Pharmacother 2017; 18: 1225-33.

16. Shirazi LF, Bissett J, Romeo F, et al. Role of Inflammation in Heart Failure. Curr Atheroscler Rep 2017; 19: 27.
17. Ünlü $B$, Küme $T$, Emek $M$, Örmen $M$, Doğan $Y$, Şişman AR, Ergör G, Çoker C. Effect of blood cell subtypes lysis on routine biochemical tests. J Med Biochem 2018; 37: 67-77.

18. Boulogne $M$, Sadoune $M$, Launay $J M$, et al. Inflammation versus mechanical stretch biomarkers over time in acutely decompensated heart failure with reduced ejection fraction. Int J Cardiol 2017; 226: 53-9.

19. Zhang Y, Bauersachs J, Langer HF. Immune mechanisms in heart failure. Eur J Heart Fail 2017; 19: 1379-89.

20. Colombo PC, Onat D, Sabbah HN. Acute heart failure as sacute endothelitis «-Interaction of fluid overload and endothelial dysfunction. Eur J Heart Fail 2008; 10: 170-5.

21. Ünlü $B$, Küme $T, M D$, Emek $M$, Örmen $M$, Doğan $Y$, Sişman RA, Ergör G, Çoker C. Effect of Blood Cell Subtypes Lysis on Routine Biochemical Tests. J Med Biochem 2019; 37: 67-77.

22. Ijsselmuiden AJ, Musters RJ, de Ruiter G, et al. Circulating white blood cells and platelets amplify oxidative stress in heart failure. Nat Clin Pract Cardiovasc Med 2008; 5: 811-20.

23. Ponikowski, AA Voors, SD Anker, H. Bueno, et al. 2016 ESC guidelines for the diagnosis and treatment of acute and chronic heart failure: the task force for the diagnosis and treatment of acute and chronic heart failure of the European Society of Cardiology. Rev ESP Cardiol 2016 Dec; 69(12): 1167.

24. Ridker PM, Everett BM, Thuren T, et al. Antiinflammatory Therapy with Canakinumab for Atherosclerotic Disease. N Engl J Med 2017; 377(12): 1119-31.

25. Ridker PM, Cushman M, Stampfer MJ, et al. Inflammation, aspirin, and the risk of cardiovascular disease in apparently healthy men. N Engl J Med 1997; 336: 973-9.

26. Ridker PM, Hennekens $\mathrm{CH}$, Buring JE, et al. C-reactive protein and other markers of inflammation in the prediction of cardiovascular disease in women. $\mathrm{N}$ Engl J Med 2000; 342: 836-43.

27. Stoner L, Lucero AA, Palmer BR, et al. Inflammatory biomarkers for predicting cardiovascular disease. Clin Biochem 2013; 46: 1353-71.

28. Guasti L, Dentali F, Castiglioni L, et al. Neutrophils and clinical outcomes in patients with acute coronary syndromes and/or cardiac revascularization. A systematic review on more than 34,000 subjects. Thromb Haemost 2011; 106: 591-9.

29. Pedrazzani C, Mantovani G, Fernandes E, et al. Assessment of neutrophil-to-lymphocyte ratio, platelet-tolymphocyte ratio and platelet count as predictors of longterm outcome after $\mathrm{RO}$ resection for colorectal cancer. Sci Rep 2017; 7: 1494.

30. Cooper HA, Exner DV, Waclawiw MA, et al. White blood cell count and mortality in patients with ischemic and nonischemic left ventricular systolic dysfunction (an analysis of the Studies Of Left Ventricular Dysfunction (SOLVD). Am J Cardiol 1999; 84: 252-7.

31. Tamhane UU, Aneja S, Montgomery D, et al. Association between admission neutrophil to lymphocyte ratio and 
outcomes in patients with acute coronary syndrome. Am J Cardiol 2008; 102: 653-57.

32. Chen D, Assad-Kottner C, Orrego C, et al. Cytokines and acute heart failure. Crit Care Med 2008; 36(1 Suppl): S9-16.

33. Rudiger A, Burckhardt OA, Harpes $P$, et al. The relative lymphocyte count on hospital admission is a risk factor for long-term mortality in patients with acute heart failure. Am J Emerg Med 2006; 24:451- 54.

34. Milo-Cotter O, Felker GM, Uriel N, et al. Patterns of leukocyte counts on admissions for acute heart failurepresentation and outcome-results from a community based registry. Int J Cardiol 2011; 148: 17-22.

35. Benites-Zapata VA, Hernandez AV, Nagarajan V, et al. Usefulness of neutrophil-tolymphocyte ratio in risk stratification of patients with advanced heart failure. The American Journal of Cardiology 2015; 115: 57-61.

36. Durmus E, Kivrak T, Gerin F, et al. Neutrophil-to-lymphocyte ratio and platelet-tolymphocyte ratio are predictors of heart failure. Arquivos brasileiros de cardiologia 2015; 105: 606-13.
37. Weber C, Zernecke A, Libby P. The multifaceted contributions of leukocyte subsets to atherosclerosis: Lessons from mouse models. Nature reviews. Immunology 2008; 8: 802-15.

38. Azab B, Zaher M, Weiserbs KF, et al. Usefulness of neutrophil to lymphocyte ratio in predicting short and long-term mortality after non-st elevation myocardial infarction. The American Journal of Cardiology 2010; 106: 470-76.

39. Siniorakis EE, Tsarouhas K, Tsitsimpikou C, et al. Neutrophil to Lymphocyte (N/L) and Platelet to Lymphocyte $(\mathrm{P} / \mathrm{L})$ Ratios in Differentiating Acute Heart Failure from Respiratory Infection. Curr Vasc Pharmacol 2017; 15: 477-81.

40. Lassus JP, Siirilä-Waris K, Nieminen MS, et al. Long-term survival after hospitalization for acute heart failuredifferences in prognosis of acutely decompensated chronic and new-onset acute heart failure. Int J Cardiol 2013; 168: 458-62. 